\title{
VEGETABLE CONSUMPTION PATTERN \\ OF HOUSEHOLDS IN SELECTED AREAS OF THE OLD RIVERS STATE IN NIGERIA
}

\author{
Hart $A D^{* 1}$, Azubuike $C U^{2}$, Barimalaa $I S^{3}$ \\ and SC Achinewhu
}

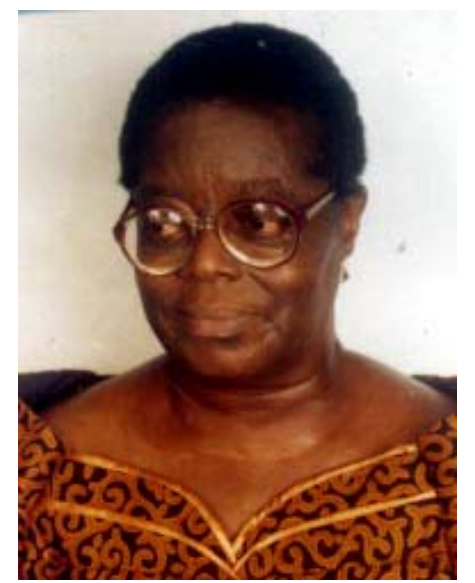

AleXANDer Hart

1. Associate Professor, Department of Food Science and Technology, Rivers State University of Science and Technology, Nkpolu-Oroworukwo, P.M.B 5080, Port Harcourt, Nigeria.

Tel: 08037244818,E-mail: dradhartust@yahoo.co.uk

2. Principal Dietician, Dietetic Unit,Abia State University Teaching Hospital, Aba. Tel: 08037057155, E-mail: uchyuch@yahoo.com

3. Senior Lecturer, Department of Food Science and Technology,

Rivers State University of Science and Technology, Nkpolu-Oroworukwo, P.M.B 5080, Port Harcourt, Nigeria.

Tel: 08037059094, E-mail: barimalaa@yahoo.com

4. Professor of Nutritional Biochemistry, Department of Food Science and Technology, Presently Vice Chancellor, Rivers State University of Science and Technology Nkpolu-Oroworukwo, P.M.B 5080, Port Harcourt, Nigeria. Tel: 08033097858; 084-233288; 084-230720 E-mail: achinewhu@yahoo.com 


\section{ABSTRACT}

The vegetable consumption pattern of households in selected areas in the old Rivers State (now Rivers and Bayelsa States) in Nigeria was investigated. Areas studied were Port Harcourt the State capital, Igwuruta, Ahoada and Kaiama. Results

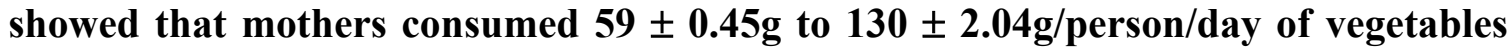
between the months of May and July, the peak season of vegetable production. Factors that influenced vegetable consumption were found to be chiefly season and culture. Other factors were availability/price for $\mathbf{4 3 . 8 \%}$ of households in Kaiama, a riverine community, while taste and nutrition knowledge wielded minor influences. Leafy vegetables were consumed at least four times per week in Igwuruta and Port Harcourt, while households in Ahoada and Kaiama, where culture had strong influence, consumed them only occasionally. Vegetables consumed were mainly pumpkin leaves (Telfairia occidentialis) and okro (Abelmoschus esculentus) in areas where season played a strong role. In areas where culture had a strong influence, bitterleaf, a leafy vegetable that undergoes rigorous process of squeezing and washing and is only scantly used in soups, was the vegetable of choice. Other vegetables less frequently consumed were Amaranthus hybridus, Pterocarpus spp., Gnetum africanum and Piper guineense leaves. These were used chiefly in various soup dishes eaten as accompaniments with the starchy staples. Other dishes in which leafy vegetables were consumed were pottage in those areas of high vegetable consumption, and occasionally in stew by all households investigated. Household size of 5 to 8 persons consumed their soup dishes between two and four days, while larger households of nine and above ate their soups in one day. However, households with deep freezer facilities stored their soup dishes for up to seven days. In spite of the reasonable consumption of vegetables during the peak season of production, reports of micronutrient deficiencies in Nigeria are rife, indicating a need for intervention. Possible reasons for the high prevalence of micronutrient deficiencies are seasonal variations in vegetable production, inadequate processing and preservation of vegetables for all year distribution and culture which may limit adequate consumption of leafy vegetables even when they are in abundance. This situation underscores the need for nutrition education, coupled with a program on dietary diversification to create awareness, increase production, processing, preservation and consumption of vegetables.

Key words: $\quad$ Vegetable consumption, season, culture, nutrition education

\section{FRENCH}

\section{RÉSUMÉ}

Le modèle de consommation de légumes tel que pratiqué par des ménages dans des régions sélectionnées de l'ancien Etat de 'Rivers' (aujourd'hui Etats de Rivers et de Bayelsa) au Nigeria a fait l'objet de recherche. Les régions étudiées étaient Port 
Harcourt, la Capitale de l'Etat, Igwuruta, Ahoada et Kaiama. Les résultats ont montré que des mères consommaient entre $59 \pm 0.45 \mathrm{~g}$ et $130 \pm 2.04 \mathrm{~g} /$ personne/jour de légumes entre les mois de mai et de juillet, la saison maximale de production de légumes. Il s'est avéré que les facteurs qui ont influencé la consommation de légumes étaient principalement la saison et la culture. D'autres facteurs étaient la disponibilité/le prix pour $43.8 \%$ des ménages de Kaiama, une communauté riveraine, tandis que le goût et la connaissance en matière de nutrition ont joué une influence mineure. Les légumes verts étaient consommés au moins quatre fois par semaine à Igwuruta et à Port Harcourt, tandis que les ménages d'Ahoada et de Kaiama, où la culture a une forte influence, ne les consommaient que de temps à autre. Les légumes consommés étaient principalement les feuilles de courge (Telfairia occidentialis) et okro (Abelmoschus esculentus) dans les régions où la saison jouait un grand rôle. Dans les régions où la culture a une forte influence, la feuille amère, un légume vert qui subit un processus rigoureux qui consiste à le presser et le laver, et qui n'est utilisé que légèrement dans les soupes, était le légume favori. D’autres légumes moins fréquemment consommés étaient les feuilles d'Amaranthus hybridus, de Pterocarpus spp., devGnetum africanum et de Piper guineense. Ces légumes étaient utilisés surtout dans les différentes variétés de soupes mangées comme des accompagnements avec les aliments de base riches en féculents. D'autres plats dans lesquels des légumes verts étaient consommés étaient des potages dans ces régions de grande consommation de légumes, et de temps à autre en ragoût par tous les ménages qui ont fait l'objet de l'étude. Les ménages d'une taille de 5 à 8 personnes consommaient leurs plats de soupes entre deux et quatre jours, tandis que de plus grands ménages de neuf personnes et plus mangeaient leurs soupes en une journée. Cependant, les ménages qui ont des réfrigérateurs conservaient leurs plats de soupes jusqu'à sept jours. En dépit de la consommation raisonnable de légumes pendant la saison maximale de production, les rapports sur les carences en micronutriments au Nigeria vont bon train, indiquant une nécessité d'intervention. Les raisons possibles qui expliquent cette prévalence élevée des carences en micronutriments sont les variations saisonnières en production de légumes, un traitement inadéquat et une mauvaise conservation des légumes à répartir sur toute l'année, ainsi qu'une culture qui peut limiter une consommation adéquate des légumes verts même lorsqu'il y en a en abondance. Cette situation met en exergue la nécessité d'une éducation portant sur la nutrition, complétée par un programme sur la diversification alimentaire en vue d'une prise de conscience, d'une augmentation de la production, du traitement, de la conservation et de la consommation des légumes.

Mots-clés: Consommation de légumes, saison, culture, éducation portant sur la nutrition 


\section{INTRODUCTION}

Besides their aesthetic value in food presentation, vegetables enhance the nutritional quality of diets because of their richness in vitamins and minerals such as carotene (provitamin A), ascorbic acid, riboflavin, iron, iodine, calcium etc [1,2]. In addition to their high concentration of micronutrients, vegetables provide little dietary energy, making them valuable in energy limited diets. The fibre content has been reported to have beneficial effects on blood cholesterol and aids in the prevention of large bowel diseases, while in diabetic subjects, they improve glucose tolerance $[3,4,5,6]$.

In spite of these attributes, coupled with the abundance of vegetables particularly among farming communities in Nigeria, the 1990 World Summit on Children identified three micronutrient deficiencies worldwide. These are: iodine deficiency disorder (IDD), iron deficiency anemia (IDA)and vitamin A deficiency (VAD). Micronutrient malnutrition has been identified as a widespread problem world wide with serious economic health consequences. Recent estimates show that 25.4 million children suffer from clinical and marginal vitamin A deficiency, while 2.2 billion people, mainly children and pregnant women suffer from iron deficiency anemia [7,8]. Similarly, a recent survey report in Nigeria showed that at the national level, $24.8 \%$ of children under 5 suffered from subclinical vitamin A deficiency while $4.7 \%$ were vitamin A deficient, making a total of $29.5 \%$ who suffered from clinically deficiency. In the women, $13.1 \%$ of mothers and $19.2 \%$ of pregnant women were at risk of vitamin A deficiency. Iron status profile showed that $27.5 \%$ children were at different stages of iron deficiency as $8.1 \%$ had depleted iron stores. In the women, approximately $24.3 \%$ of mothers and $35.3 \%$ of pregnant women were at different stages of iron deficiency. Iodine status profile indicated that $27.5 \%$ of children, $30.7 \%$ of mothers and $10 \%$ of pregnant women had various degrees of iodine deficiency [10]. This dismal picture of the micronutrient status of Nigerians spells of serious consequences. The consequences of vitamin A deficiency (VAD) include night blindness, Bitot's spot, corneal xerosis and corneal scars or ulcers. Other serious consequences have been shown to include increased morbidity and mortality of infants, children and pregnant women, poor growth of children and susceptibility to anemia through interface with iron transport and utilization for hemoglobin synthesis [11]. The risk of iron deficiency increases during periods of rapid growth, notably in infancy, adolescence and pregnancy. The consequences of iron deficiency include reduced work capacity, impaired body temperature regulation, impairments in behaviour and intellectual performance and decreased resistance to infections. Iodine deficiency disorders (IDD) have serious adverse effects including cretinism, goiter, impaired cognitive function, impaired growth, infant mortality, low 
birth weight and stillbirths. IDD remains a major threat to the health and development of populations world wide $[10,11]$.

In some parts of Nigeria, green leafy vegetables have gained a widespread acceptance as a dietary constituent, generally forming a substantial portion of the diet in the preparation of soups and stews [9]. Some of the vegetables may be eaten raw or as a vegetable salad when shredded and cooked with water extracts of oil palm fruits. This is generally eaten as an accompaniment with the starchy staples [12]. The present study was prompted by the paucity of information on the vegetable consumption pattern and factors influencing their consumption in the old Rivers State in Nigeria.

\section{STUDY LOCATION}

The old Rivers State (now Rivers and Bayelsa States) is located in the tropical rain forest zone of Nigeria and was made up of upland and riverine areas with a population of about 3.9 million people. The upland people are mostly crop farmers, while the riverine areas consist predominantly of fisherfolk.

\section{SAMPLE SELECTION/SAMPLING TECHNIQUE}

Selected communities in Port Harcourt (the State capital), Ahoada and Igwuruta (upland) and Kaiama (riverine) were chosen for the study. From the list of enumeration areas (EAs) obtained from the National Population Commission, was randomly selected one EA per community. Using the EA map showing where household numbering would start and end, eligible households were identified. Eligibility in the study which was part of a larger study on health assessment, was based on households with a mother and child a under-five-years of age-groups most vulnerable to the ravages of malnutrition. A household was defined as a family unit that feeds from the same pot and had a recognized head of authority. Sixty eligible households were randomly selected from the EA in each selected community, making a total of 240 households in all.

\section{ADMINISTRATION AND COLLECTION OF DATA}

Information on the pattern of vegetable consumption was obtained by means of semistructured questionnaire administered by the investigator on the mother in each household. The quantity of vegetables consumed by the mother was obtained from an estimated weight of the vegetables obtained or otherwise procured, the type of food preparation for which it was used, the household size and the number of times the food was eaten by the mother. Factors influencing vegetable consumption were determined from a checklist in which the respondent was made to select the most appropriate option. Data on diversity of vegetables and the soup preparations in which they were consumed, household size and number of days a soup preparation lasted as well as leafy vegetable usage were also obtained. 


\section{DATA ANALYSIS}

Data collected were subjected to analysis by simple percentage.

\section{RESULTS}

Table 1 shows the mean daily intake of vegetables consumed by the mother in the household to be $130 \pm 2.04 \mathrm{~g}$ in Igwuruta, $64 \pm 0.56 \mathrm{~g}$ in Ahoada, $91 \pm 0.33 \mathrm{~g}$ in Port Harcourt and $59 \pm 0.45 \mathrm{~g}$ in Kaiama. Factors influencing the consumption of vegetables (Table 2) showed that availability/price only affected $43.8 \%$ of households in Kaiama, while 77.0 and $69.2 \%$ in Igwuruta and Port Harcourt, respectively were influenced by season. Culture influenced 76.9 and $53 \%$ of households in Ahoada and Kaiama, respectively. 15.4, 19.2 and 3.9\% in Igwuruta, Ahoada and Port Harcourt, respectively were influenced by taste and 7.7, 3.9 and $26.9 \%$ of households in Igwuruta, Ahoada and Port Harcourt, respectively by nutrition knowledge. Table 3 showns the weekly frequency of vegetable consumption by households. Leafy vegetables were consumed more than four times per week by $60.2 \%$ and $65.4 \%$ of households in Igwuruta and Port Harcourt, respectively, two to three times per week by $39.8 \%, 11.5 \% 34.6 \%$ and $12.5 \%$ of households in Igwuruta, Ahoada, Port Harcourt and Kaiama, respectively, once a week by $7.7 \%$ of households in Ahoada and only occasionally by $80.8 \%$ and $87.5 \%$ of households in Ahoada and Kaiama, respectively.

Bitterleaf (Vernonia amygdalina) was consumed more than four times per week by $88.5 \%$ and $75 \%$ of households in Ahoada and Kaiama, respectively, two to three times by $11.5 \%, 7.7 \%$ and $25 \%$ of households in Ahoada, Port Harcourt and Kaiama, respectively, once a week by $15.4 \%$ and $19.2 \%$ of households in Igwuruta and Port Harcourt, respectively and only occasionally by $84.6 \%$ and $73.1 \%$ of households in Igwuruta and Port Harcourt, respectively.

Okro (Abelmoschus esculentus) was consumed two to three times per week by $30.8 \%$, $7.7 \%, 57.7 \%$ and $25 \%$ of households in Igwuruta, Ahoada, Port Harcourt and Kaiama, respectively, and once a week by $69.2 \%, 92.3 \%, 42.3 \%$ and $75 \%$ of households in Igwuruta, Ahoada, Port Harcourt and Kaiama, respectively.

Table 4 presents the diversity of vegetables and the soup preparations in which they were consumed by households. Egusi with bitterleaf was consumed by 15, 8, 20 and $13 \%$ of households in Igwuruta, Ahoada, Port Harcourt and Kaiama, respectively, okro with bitterleaf by 8 and $4 \%$ of households in Ahoada and Port Harcourt, ogbono with bitterleaf by 8 and $4 \%$ of households in Ahoada and Port Harcourt, banga (water extracts 
of oil palm fruit) with bitterleaf by $48 \%$ of households in Ahoada, and ogbono with bitterleaf by $8 \%$ of households in Port Harcourt. Pumpkin (Telfairia occidentalis) leaves were prepared with the following condiments: okro by 46, 12, 20 and 17\% of households in Igwuruta, Ahoada, Port Harcourt and Kaiama, respectively, achi (seed of brachystegia spp) by 23,4 and $8 \%$ of households in Igwuruta, Ahoada and Port Harcourt, respectively, ogbono by 12 and 7\% of households in Port Harcourt and Kaiama, respectively, egusi and okro combination by 4 and 13\% in Port Harcourt and Kaiama respectively and egusi by $8 \%$ in either Igwuruta, Ahoada or Port Harcourt.

Other lesser used vegetables such as African spinach (Amaranthus hybridus), oha (Pterocarpus spp) with uziza (Piper guineense) leaves were consumed with egusi by $4 \%$ of households in Port Harcourt, while ukazi (Gnetum africanum) was consumed by 8 and $4 \%$ of households in Igwuruta and Port Harcourt, respectively, using the condiment/soup thickener achi (Brachystegia spp).

The leafy vegetable usage by households is shown in Table 5. All households in all the communities (Igwuruta, Ahoada, Port Harcourt and Kaiama) used them in soup preparations, while in stews they were used only occasionally by $23,50,64$ and $50 \%$ of household in Igwuruta, Ahoada, Port Harcourt and Kaiama, respectively. For pottage, 100 and $96 \%$ of households in Igwuruta and Port Harcourt respectively used leafy vegetables, while all in Ahoada and $75 \%$ in Kaima used them only occasionally.

Table 6 shows the household size and number of days soup preparations lasted. In Igwuruta, Ahoada, Port Harcourt and Kaiama, households of less than 5 people consumed soup preparations that lasted 3-4 days, except in Port Harcourt with refrigeration facilities where the soups lasted up to 7 days. Fifty to $69 \%$ of households with $5-8$ people consumed soup preparations for two days in all cases, while $15-24 \%$ of households consisting of 9 or more people in Igwuruta, Ahoada and Port Harcourt consumed their soup preparations in one day.

\section{DISCUSSION}

The data from this study showed that the women in Igwuruta and Port Harcourt consumed substantially large amounts of vegetables $(130 \pm 2.04$ and $91 \pm 0.33 \mathrm{~g} /$ day $)$ compared to the mean intake of $65 \mathrm{~g}$ /day reported in western Nigeria by Oguntona [13]. This may not be surprising since the study covered the peak period of vegetable production (May to July). It is possible that these communities were inclined to consume more leafy vegetables than those in the previous study, as a later study in one of the western Nigerian villages (Ago-Iwoje) on vitamin A rich food security showed that leafy vegetables were only slightly commonly produced and consumed [14]. Adedoyin and Taylor [14] indicated that only $22 \%$ of the leafy vegetables sold or purchased from the market was consumed. In the present study, Igwuruta and Port Harcourt have season as the strongest influence on vegetable consumption (Table 2), while in both Ahoada and Kaiama where culture wielded a strong influence, vegetable consumption was fairly 
similar to the values reported by Oguntona [13]. In these cases, bitterleaf was consumed more frequently than the other leafy vegetables. Bitterleaf is unique because of the rigorous process of squeezing and washing before use, and it is only scantily used in soup preparations, notably for its flavour. Besides culture, another strong factor that influenced vegetable consumption in Kaiama was availability due to high price as reflected in Table 2. Kaiama being a remote riverine community, high cost of transportation and the high perishability of vegetables are possible constraining factors in their availability, compelling the people to rely on bitterleaf which is easily grown around the backyard. The reason for this could be deduced from the finding that food habits develop within a framework of culture which consists of values, modes of thought, customs and habits that are socially learned as people get used to what is physically available and economically feasible in their locality $[15,17]$. The same reasons could be adduced for the weak influence of taste in the study areas.

In Ahoada, culture also played a leading role in vegetable consumption despite the season of abundance and the fact of its being a farming community, showing the deep rootedness in the food culture of people as similarly reported by Adedoyin and Taylor [14]. These authors posited that willingness to consume beneficial foods could only be improved through a deliberate extension programme.

The weekly frequency of vegetable consumption (Table3) shows that majority of households (60.2 and 65.4\%) in Igwuruta and Port Harcourt, respectively consumed leafy vegetables more than four times per week. The consumption of a food item more than four times per week shows that the food is consumed almost every day in a week. When compared with a recent national survey in Nigeria covering periods of dry and rainy seasons, in the humid rain forest which includes the area under investigation, leafy vegetables were consumed more than four times per week by $40 \%$ of households [10]. This confirms the possible influence of season on vegetable consumption in the aforementioned communities. As was earlier indicated, it is also possible that households in Igwuruta and Port Harcourt are habitual consumers of leafy vegetables. In Ahoada and Kaiama on the contrary, majority of households ( 80.8 and $87.5 \%$, respectively) consumed leafy vegetables only occasionally, while bitterleaf was consumed more frequently (more than 4 times per week by 88.5 and $75 \%$ of households). While Igwuruta and Port Harcourt frequently consumed leafy vegetables as a result of season, Ahoada and Kaiama were influenced by culture to consume bitterleaf more frequently, with occasional intake of other leafy vegetables.

The consumption of okro, a fruit vegetable used as condiment, seems to follow the same pattern of leafy vegetable consumption, being consumed fairly frequently, that is, 2 to 3 times by 30 and $57.7 \%$ of households in Igwuruta and Port Harcourt. On the other hand, a large proportion of households in Ahoada and Kaiama (92 and 75\%, respectively) consumed okro only once a week. The possible explanation to this trend could be that okro is often prepared with leafy vegetables in those areas where season plays a major role in vegetable consumption. 
From the trend seen in this study, the consumption of vegetables in the areas studied is largely influenced by season, followed by culture, and to lesser degrees, by taste and nutrition knowledge. Price influenced vegetable consumption as a result of limited availability of the commodity occasioned by transportation constraints as in the case of the riverine community, Kaiama.

As would be expected, a wider variety of vegetables were consumed in Port Harcourt, the reason also being possibly due to its cosmopolitan nature, while the other communities were restricted mainly to bitterleaf, pumpkin leaves and okro.

Data from this study indicate that more than $50 \%$ of households consisted of $5-8$ members consuming soup preparations lasting 2 days. The mode of leafy vegetable consumption is chiefly as a constituent of soups, and to varying degrees in stews and pottage. In all the areas investigated, $100 \%$ of households used leafy vegetables in soups. Next to soups, leafy vegetables were consumed in pottage preparation, particularly in Igwuruta and Port Harcourt where almost all households (96-100\%) consumed them in that manner, this being partly responsible for their increased level of consumption. In Ahoada and Kaiama, to the contrary, leafy vegetables were only occasionally consumed in pottage. In the preparation of stews, leafy vegetables were used only occasionally by all households investigated, showing that it is not a common vehicle for consuming the food commodity.

The Nigerian soup consists of a pot pouri of ingredients such as water, palm oil, spices and seasonings and subject to available funds, meat and/or fish may be added with optional vegetables. The ingredients are cooked together as a sauce and eaten as an accompaniment with the starchy staple. The data on household size and number of days soup preparations lasted indicate that $50-62 \%$ of households consisted of 5-8 members who consumed on average, a pot of soup lasting 2 days. The smaller the household size, the longer the duration of the soup preparation, so that household size below 5 consumed soup preparations for 3-4 days, while those above 9 consumed their soup in one day. Except in Port Harcourt with constant electricity supply and deep freezer facilities where soups could be stored for up to 7 days, soup preparations are generally reheated several times in the day to prevent spoilage. This method of vegetable utilization has been shown to result in losses of vitamins according to Umoh and Bassir [16]. Such a situation calls for education on the proper utilization of vegetables for maximum benefits.

In spite of the reasonable intake of vegetables seen in this study, reports indicate that in Nigeria, vitamin A deficiency in mothers and children is about $11-35 \%$ in the north and middle belt and $5-30 \%$ in the south anemia is responsible for $10 \%$ of maternal mortality while the prevalence of endemic goiter is $13-37 \%$ with a national average of $20 \%$ [18]. These situations have attracted support from various organizations by way of providing intervention (Micronutrient Initiative) according to a report by FGN/UNICEF [19]. Possible explanation for the high prevalence of micronutrient deficiencies reported could be attributed to the poor traditional cooking methods as reported by Umoh and Bassir 
[16]. Furthermore, during the peak season vegetables are in abundance, but owing to inadequate processing and preservation facilities, they are scarce and expensive during the off-peak season (dry season), limiting their intakes particularly among the lowincome earners who constitute the bulk of the society [20,21].

Vegetables are the most affordable and sustainable dietary source of vitamins, trace elements and other bioactive compounds. Improved vegetable production and consumption is thus regarded as the direct, low cost method for many of the urban and rural poor to increase micronutrients in their diet [22]. This report is underscored by the recent finding about the dismal state of micronutrient nutrition of children, mothers and pregnant women in Nigeria [10]. The need for education based on dietary diversification with emphasis on enhanced consumption of vegetables year round cannot be overemphasized as indicated by recent reports [23,24].

In Nigeria, as in other developing countries of the world, the need for deliberate cultivation and consumption of locally and commonly available micronutrient rich foods have been identified as a useful step towards eliminating micronutrient deficiencies [14]. However, the influence of culture which may hinder the liberal consumption of vegetables even during the peak season of production as in Ahoada, will need to be addressed through nutrition education and extension communication programme as pointed out by Adedoyin and Taylor [12]. This will also improve nutrition knowledge which has been rated low in this study, to further enhance the consumption of vegetables.

\section{CONCLUSION}

In conclusion, this study has shown season and culture to be major influences on vegetable consumption among households in some parts of the Old Rivers State in Nigeria. Other factors include price, and to lesser degrees, taste and nutrition knowledge. Reasonable quantities of vegetables above reported qualities were consumed in areas where season wielded a strong influence on vegetable consumption. On the other hand, where culture played a major role as in Ahoada and Kaiama, the consumption of vegetables was restricted to bitterleaf, the season of abundance notwithstanding. However, in spite of the liberal consumption of vegetables which are noted for their higher content of vitamins and minerals, reports of high prevalence of micronutrient deficiency are rife in Nigeria. The tropical rain forest zone of Nigeria has a wide variety of vegetables. Regrettably, due to seasonal variations and inadequate processing and preservation facilities, vegetables are not always available year round [20]. This situation might be responsible for the high prevalence of micronutrient deficiencies reported. The influence of culture on one hand, and high price due to transportation constraints which further limit the consumption of vegetables, could be other contributory factors. Furthermore, the poor traditional method of cooking whereby soup preparations with vegetables are frequently reheated and consumed over periods of two to four days results in reported losses of micronutrients which could further limit the intake of micronutrients. Such a situation calls for education to eradicate poor food or cultural 
habits, coupled with dietary diversification for increased all year round production and consumption of vegetables and other micronutrient-rich foods. 
TABLES

Table 1

Mean intake of vegetables consumed by the mother

\begin{tabular}{ll}
\hline Locality & \multicolumn{1}{c}{ Mean intake of vegetables (g/day) } \\
\hline Igwuruta & $130 \pm 2.04$ \\
Ahoada & $64 \pm 0.56$ \\
Port Harcourt & $91 \pm 0.33$ \\
Kaiama & $59 \pm 0.45$ \\
\hline
\end{tabular}

Values show \pm standard error of mean 


\section{Table 2}

Factors influencing the consumption of vegetables among households

\begin{tabular}{lcccc}
\hline \multicolumn{1}{c}{ Factors } & \multicolumn{4}{c}{ Percentage of households } \\
& Igwuruta & Ahoada & Port Harcourt & Kaiama \\
\hline Availability/Price & 0 & 0 & 0 & 43.8 \\
Season & 77.0 & 0 & 69.2 & 0 \\
Culture & 0 & 76.9 & 0 & 56.3 \\
Taste & 15.4 & 19.2 & 3.9 & 0 \\
Nutrition Knowledge & 7.7 & 3.9 & 26.9 & 0 \\
\hline
\end{tabular}


Table 3

Weekly frequency of vegetable consumption by households in some parts of the Old Rivers State, Nigeria.

\begin{tabular}{|c|c|c|c|c|}
\hline \multirow[t]{2}{*}{ Factors } & \multicolumn{4}{|c|}{ Percentage of households } \\
\hline & Igwuruta & Ahoada & Port Harcourt & Kaiama \\
\hline \multicolumn{5}{|l|}{ Leafy Vegetables } \\
\hline 4 times or more & 60.2 & 0 & 65.4 & 0 \\
\hline $2-3$ times & 39.8 & 11.5 & 34.6 & 12.5 \\
\hline Once & 0 & 7.7 & 0 & 0 \\
\hline Occasionally & 0 & 80.8 & 0 & 87.5 \\
\hline \multicolumn{5}{|l|}{ Bitterleaf* } \\
\hline 4 times or more & 0 & 88.5 & 0 & 75 \\
\hline $2-3$ times & 0 & 11.5 & 7.7 & 25 \\
\hline Once & 15.4 & 0 & 19.2 & 0 \\
\hline Occasionally & 84.6 & 0 & 73.1 & 0 \\
\hline \multicolumn{5}{|l|}{$\mathrm{Okro}^{+}$} \\
\hline 4 times or more & 0 & 0 & 0 & 0 \\
\hline $2-3$ times & 30.8 & 7.7 & 57.7 & 25 \\
\hline Once & 69.2 & 92.3 & 42.3 & 75 \\
\hline Occasionally & 0 & 0 & 0 & 0 \\
\hline
\end{tabular}

* Bitterleaf is separated from leafy vegetables because of its unique processing method. It is valued for its flavour

+ Okro (Abelmoschus esculentus) is a slimy fruit vegetable used in soup preparations as a thickener, with/without the addition of leafy vegetable 
Table 4

Diversity of vegetables and the soup preparations consumed by households

\begin{tabular}{|c|c|c|c|c|c|c|}
\hline \multirow[t]{2}{*}{ S/No. } & \multirow{2}{*}{ Types of Soup } & \multicolumn{5}{|c|}{ Proportion (\%) of households } \\
\hline & & Vegetable & Igwuruta & Ahoada & $*$ P.H & Kaiama \\
\hline 1 & $\begin{array}{l}\text { Egusi (ground melon } \\
\text { seeds) }\end{array}$ & $\begin{array}{l}\text { Bitter leaf (Vernonia } \\
\text { amydalina) }\end{array}$ & 15 & 8 & 20 & 13 \\
\hline 2 & $\begin{array}{l}\text { Okro (Abelmoschus } \\
\text { esculentus) }\end{array}$ & Bitter leaf & - & 8 & 4 & - \\
\hline 3 & $\begin{array}{l}\text { Ogbono (dried } \\
\text { ground seeds of } \\
\text { Irvingia gabonesis) }\end{array}$ & Bitter leaf & - & 8 & 4 & - \\
\hline 4 & $\begin{array}{l}\text { Banga (water } \\
\text { extracts of oil palm } \\
\text { fruit) }\end{array}$ & Bitter leaf & - & 48 & - & - \\
\hline 5 & Ogbono & Bitter leaf & - & - & 8 & - \\
\hline 6 & Okro & $\begin{array}{l}\text { Pumpkin leaves } \\
\text { (Telfaira occidentalis) }\end{array}$ & 46 & 12 & 20 & 17 \\
\hline 7 & $\begin{array}{l}\text { Achi (ground seeds } \\
\text { of Brachystegia spp) }\end{array}$ & Pumpkin leaves & 23 & 4 & 8 & - \\
\hline 8 & Ogbono & Pumpkin & - & - & 12 & 7 \\
\hline 9 & Egusi, Okro & Pumpkin leaves & - & - & 4 & 13 \\
\hline 10 & Egusi & Pumpkin leaves & 8 & 8 & 8 & - \\
\hline 11 & Egusi & $\begin{array}{l}\text { African spinach } \\
\text { (Amaranthus } \\
\text { hybridus) }\end{array}$ & - & - & 4 & - \\
\hline 12 & Egusi & $\begin{array}{l}\text { Oha (Pterocarpus } \\
\text { spp) and uziza (Piper } \\
\text { guineense) leaves }\end{array}$ & - & - & 4 & - \\
\hline 13 & Achi & $\begin{array}{l}\text { Ukazi (Gnetum } \\
\text { africanum) }\end{array}$ & 8 & - & 4 & - \\
\hline
\end{tabular}

* Port Harcourt 


\section{Table 5}

Leafy vegetable usage by households

\begin{tabular}{lcccc}
\hline \multirow{2}{*}{ Item } & \multicolumn{4}{c}{ Percentage of households } \\
& Igwuruta & Ahoada & ${ }^{+}$Port Harcourt & Kaiama \\
\hline Soup & 100 & 100 & 100 & 100 \\
Stew* & 23 & 50 & 64 & 50 \\
Pottage & 100 & $100^{*}$ & 96 & $75^{*}$ \\
\hline
\end{tabular}

${ }^{+}$Port Harcourt

*Used only occasionally

Table 6

Household size and the number of days a soup preparation lasted

\begin{tabular}{lccc}
\hline Locality & Household Size & $\begin{array}{c}\text { Proportion of } \\
\text { Households } \mathbf{( \% )}\end{array}$ & $\begin{array}{c}\text { No. of Days Soup } \\
\text { Lasted }\end{array}$ \\
\hline Igwuruta & $<5$ & 23 & $3-4$ \\
& $5-8$ & 62 & 2 \\
& 9 and above & 15 & 1 \\
Ahoada & $<5$ & 19 & 3 \\
& $5-8$ & 62 & 2 \\
Port Harcourt & 9 and above & 19 & 1 \\
& $<5$ & 7 & $7 *$ \\
Kaiama & $5-8$ & 69 & 2 \\
& 9 and above & 24 & 1 \\
& $<5$ & 50 & 2 \\
& $5-8$ & 50 & -4 \\
\hline
\end{tabular}

* Stored in the deep freezer 


\section{REFERENCES}

1. Ihekoronye AI and PO Ngoddy Tropical Fruits and Vegetables. In: Integrated Food Science and Technology for the Tropics, Macmillan Publ. Ltd.; London and Basingstoke 1985; $293-311$.

2. Shiundu KM Role of African Leafy Vegetables (ALVs) in Alleviating Food and Nutrition Insecurity in Africa. AJFNS, 2002; 2: (2) 96 - 97.

3. Burkitt DP Epidemiology of Large Bowel Disease: The Role of Fibre. In: JML Stephen (Ed). Fibre in Human Nutrition. Nutrition Soc. Symposia Report Series No. 5,$1973 ; 145-149$.

4. Trowell H Dietary Fibre, Ischaemic Heart Diseases and Diabetes Mellitus. In: AC Field (Ed). Fibre in Human Nutrition. Nutrition Society Symposia Series No. 5,$1973 ; 151-157$.

5. IFT - Institute of Food Technology. Quality of Fruits and Vegetables. A Scientific Status Summary by the Institute of Food Technology Expert Panel on Food Safety and Nutrition. 1990; 44: (6), $1-5$.

6. Jenkins DJA Dietary Fibre. Fibre Analogues and Glucose tolerance: Importance of Viscosity. Br. Med. J. 1978;1: $1392-1394$.

7. WHO Prevalence of Vitamin A Deficiency. Micronutrient Deficiency Information System (MDIS) Working Paper No. 2, World Health Organization (NUT) 95.3 Geneva: WHO, 1995.

8. World Bank, World Bank Development in Practice Enriching Lives. Overcoming Vitamin and Mineral Malnutrition in Development Countries, Washington DC 1994.

9. Ifon ET and O Bassir The Nutritive Value of Some Nigerian Leafy Vegetables. Part 2: The Distribution of Protein, Carbohydrates (including ethanol, soluble sugars) crude fat, fibre and ash. Food Chem., 1980; 5:231 - 235.

10. IITA, Nigeria Food Consumption and Nutrition Survey 2001-2003. An FG/IITA/USAID/UNICEF/USDA Report, 2004.

11. ACCN/SCN. What Works? A Review of the Efficacy and Effectiveness of Nutrition Interventions. Nutrition Policy Paper no. 19, ADP and Development Series No. 5; 1990.

12. Eyo SM, and HJ Abel Chemical Composition and Amino Acid Contents of Gnetum africanum, Heinsia crimita and Piper guineense. Nig. J. Nutr. Sci., 1980; 
4: $57-62$.

13. Oguntona T Green Leafy Vegetables. In: (Ed) AU Osagie and OU Eka, Nutritional Quality of Plant Foods. 1998; Ch. 5: 120-133.

14. Adedoyin SA and OA Taylor Homestead Nutrition Garden Project: An Extension Communication Strategy for Eliminating Vitamin A Defiency (VAD) Among Poor Households in Nigeria. Nig. J. Nutr. Sci. 2000; 21:

$1 \& 2,34-40$.

15. Omololu A Changing Food Habits in Africa. Ecol. Fd. Nutr. 1971; 1: $165-167$.

16. Umoh IB and $\mathbf{O}$ Bassir Nutrient Changes in Some Traditional Peasant Foods During Cooking. Part 1: Vitamin Changes. Fd. Chem. 1977; 2: 155-160.

17. Gifft HG Washbon MB and GG Harrison The Development of Food Consumption Patterns. In: WH Marshall (Ed.) Nutrition, Behaviour and Change, Prentice - Hall, Inc., Eaglewood Cliffs, New Jersey, 1975; 25 - 53.

18. UNICEF. Child Survival, Protection and Development (CSPD) in Nigeria. Key Social Statistics. National Planning Commission/UNICEF, 1995.

19. Federal Government of Nigeria/UNICEF. (FGN/UNICEF) Children's and Women's Rights in Nigeria: A Wake-Up Call. Situation Assessment and Analysis 2001.

20. Omueti $\mathbf{O}$ and $\mathbf{O}$ Adepoju Research Note: Preliminary Assessment of the Effect or Processing and Storage on the Quality of Five Local Vegetables. Nig. Fd. J. 1998; 6: $67-71$.

21. Nelson PE Aseptic Bulk Processing of Fruit and Vegetables. Fd Technol. 1990; 44: (2) 96-106.

22. FAO. Home-Based Vegetable Gardens and other strategies to overcome Micronutrient Malnutrition in Development Countries. 2003; 32: 17-23. Vijayaragharan K, MU Nayaka, MS Bamji, GNV Ramana and

23. V Reddy Home Gardening for Combating Vitamin A Deficiency in Rural India. Fd. Nutr. Bull., 1997; 18: $337-343$.

24. Chittchang U, S Jittinandana, P Sungpuag, V Chavasit, and E Wasantwisut Recommending Vitamin A - Rich Foods in Southern Thailand. Fd. Nutr. Bull, United Nations University Press. 1999; 20(2), 238 - 242. 


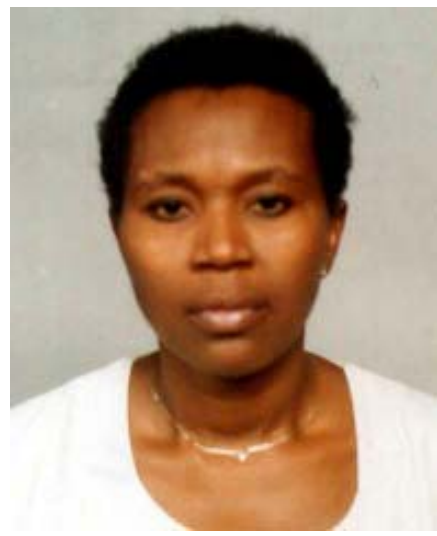

AZUBUKIE CU

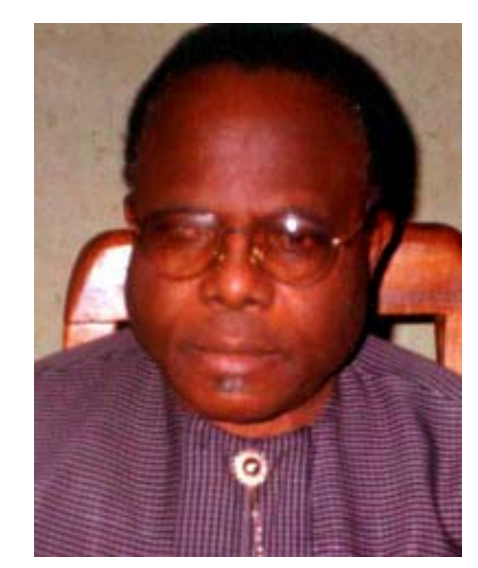

ACHINEWHU SC

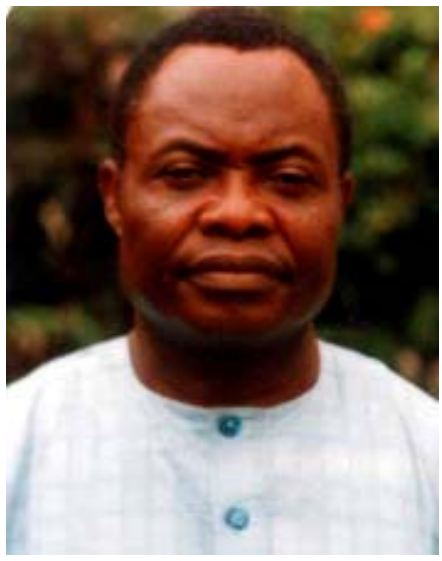

BARIMALAA IS 